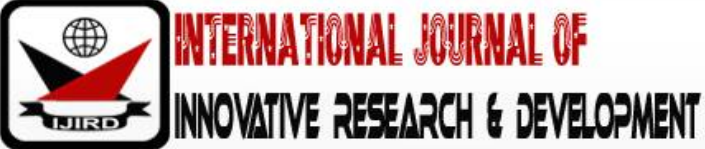

ISSN 2278 - 0211 (Online)

\section{Comparative Study of Sesame and Soybean Farming to Poverty Reduction among Rural Farmers in Benue State-Nigeria}

\author{
Sesugh Uker \\ Research Fellow, Institute of Food Security, \\ University of Agriculture Makurdi-Nigeria \\ Nicola Cannon \\ Principal Lecturer, Royal Agricultural University, Cirencester, \\ Gloucestershire, United Kingdom
}

\begin{abstract}
:
The research relates the prospects of sesame and soybean to poverty reduction among rural farmers in Nigeria. Purposive sampling was used to select 200 farmers for the study. Gross margin analysis and Foster Greer Thorbecke Index (FGT) measure of poverty were used to analyse data collected to meet the objectives of the study. The results reveal that sesame farmers were having a higher average annual gross margin and making more profit per hectare from their farming enterprise than the soybean farmers. Farmers in the respective farming systems were poor as indicated by their respective poverty per head count $\left(\alpha_{0}\right)$ values of 0.9400 and 0.9000 respectively for sesame and soybean enterprises. The poverty depth in this research revealed that majority of the farmers in the respective farming system were living below the poverty line. The research, therefore, concludes that sesame farmers were making more profit from their farming business as compared to soybean farmers.
\end{abstract}

Keywords: Comparative, sesame, soybean, farming systems, poverty, rural

\section{Background}

Sesame is cultivated on an average area of 7.8milion hectares around the world accounting for the total output of about 3.84million tons per year (Gupta 2015). The leading producers on per country basis include China, India, Paraguay, Myanmar, Ethiopia, Uganda, Somalia, Tanzania, Paraguay and Nigeria (Glin et al. 2013 and Ayana 2015). The most produced oil crops and products in Nigeria however include, palm oil/palm kernel, soybean/ soybean oil, and other oils (including peanut, cottonseed, coconut/copra, sesame seeds, rapeseeds, mustard seeds, castor seed, sunflower seed and linseed) contributing 70 percent, 25 percent, and 5 percent, respectively, to the local supply (Nzeka 2014). In spite of the lower popularity of sesame among the oil crops, it still remains a good economic crop for farming households in Nigeria (Olowe et al. 2009; Abu et al. 2012; Glin et al. 2013).

Sesame is regarded as one of the most important cash crops among smallholder rural farmers in Nigeria (Abu et al. 2011 and Gupta 2015); it is often regarded as a smallholder crop with good intercropping benefits. Its production in the country is concentrated in Benue and Nasarawa states which accounts for 40, 000 tons of the national share annually (Umar et al. 2011; Umar and Ibrahim 2012). However, the intensity of cultivation and information regarding yield and productivity are rarely available (Abu et al. 2011). Further, Abu et al. (2012) opined that there has been a steady shift from the cultivation of sesame to soybean in Nigeria due to the increasing global market demand for soybean. Umar et al. (2015) infers that farmers' negligence to sesame farming has made the crop less attractive thus affecting the quality of life of its growers. Some research has been carried out on the relative importance of this crop on the livelihoods of small-scale farmers in Nigeria (Umar et al. 2015; Nyiatagher and Ocholi 2015) but have failed to compare its place among other oilseed crops as an instrument for poverty mitigation. This study will compare the profit potentials of sesame and soybean farming enterprises in respect to the poverty status of farmers and how it affects the welfare of rural farmers cultivating them in Nigeria.

\section{Methodology}

\subsection{Study Area}

This study was carried out in Benue State which is located in the North central region of Nigeria commonly referred to as the Middle belt. The State is situated between latitude $6^{\circ} 29 \mathrm{~N}$ and $8^{\circ} 7 \mathrm{~N}$ and between longitude $7^{\circ} 44 \mathrm{E}$ and $9^{\circ} 55 \mathrm{E}$ of the equator (Uker and Orkar 2019). The state is estimated to have a land area of about 30, 955km² with a 
prominent feature of the Benue River (Nyiatagher and Ocholi 2015) and it is also referred to as the nation's food basket due to diversity in the fertility of the soil which allows for the cultivation of different major food and cash crops including yam, cassava, potatoes, maize, sorghum, rice, groundnut, soybean, sesame, and raring of livestock. The state is bordered by Nasarawa, Kogi, Cross River, and Enugu States to the North, West, South and Southwest respectively. Furthermore, Benue State is also bordered Southeast by the Republic of Cameroon (Uker and Orkar 2019). The population of the State is estimated at about 4.2 million with three majority ethnic groups namely, Tiv, Idoma and Igede as $75 \%$ of the entire population still live in the rural areas (Nyiatagher and Ocholi 2015).

\subsection{Sampling Procedure}

Benue State consists of 23 Local Government Areas but for the purpose of this study, four Local Government Areas namely; Guma, Gwer East, Gwer West and Buruku were purposively selected due to the fact that sesame and soybean production were predominantly practiced in these areas. Primary and secondary data were used to draw out information relevant to the study. Considering the variability of the population size of sesame and soybean growers in the study area, primary data was collected with the aid of questionnaire by purposively sampling 50 farmers each from the selected Local Government Areas who cultivate both sesame and soybean thus giving a total sample size of 200 farmers in the entire study area to have a reasonable and acceptable sample size for data analysis. Secondary data was drawn out from other literatures relevant to the study.

\subsection{Analytical Technique}

Descriptive and inferential statistics were used to analyze data collected for the study. Analytical outputs were presented using frequencies, percentages, Gross Margin Analysis and Foster Greer Thorbecke Index (FGT). The excel package was also used for presentation of bar charts.

\subsection{Model Specification}

\subsubsection{Gross Margin Analysis}

The gross margin of farmers in sesame and soybean farming enterprise was expressed as:

GM=TR - TVC - - . - - (1); Where;

$\mathrm{GM}=$ Gross margin per hectare

$\mathrm{TR}=$ Total revenue per hectare

TVC=Total variable cost per hectare

Net profit in the farming systems was expressed as;

NP=TR-TC - . - . - - (2); Where,

$\mathrm{NP}=$ Net Profit

$\mathrm{TR}=$ Total Revenue

$\mathrm{TC}=$ Total Cost which is the sum of the TVC and the Total Fixed Cost (TFC).

\subsubsection{Foster Greer Thorbecke Index (FGT)}

The Foster Greer Thorbecke (FGT) Index was used to determine the poverty status of respondents in both farming enterprises. This was made possible by adopting the new poverty line set up by the World Bank at $\$ 1.25$ (Ravallion 2010; OECD and FAO 2016) which assumed the amount of 380 Nigerian Naira was adopted to compare the Food Energy Intake (Ravallion 2010) of households in the respective farming enterprises. Jensen and Miller (2010) reported that calorie intake and minimum calorie thresholds are often used to set poverty line for many developing countries. In using this poverty line set to determine the poverty status of households, nutritional information has to be converted into monetary value and people who cannot afford the Food Energy Intake Cost are referred to as the poor households (Bellù and Liberati 2005). According to Taylor and Lybbert (2015), the measurement of this kind of poverty index depends on three alpha $(\alpha)$ values ranging from 0 to 2 . Alpha zero $\left(\alpha_{0}\right)$ explains the proportion of the population who are poor, alpha one $\left(\alpha_{1}\right)$ explains the average proportion that falls below the poverty line, and alpha two $\left(\alpha_{2}\right)$ explains the severity of poverty among the poorest and the poor household which is often referred to as the squares of the poverty gap. The higher the value assumed by alpha in a particular vector (in this case farming enterprise), the higher the severity of poverty recorded in that particular vector. This is expressed as;

$P_{\alpha}=\frac{1}{n} \sum_{i=1}^{q}\left(\frac{z-y_{i}}{z}\right)^{\alpha} \quad(\alpha \geq 0)$

Where;

$\mathrm{P} \alpha=$ Foster Greer and Thorbecke index $(0 \leq \mathrm{P} \alpha \geq 1)$

$\mathrm{n}=$ Total Household observation

$\mathrm{z}=$ Poverty Line (1.25 US Dollar per day $=$ N380)

$\mathrm{y}_{\mathrm{i}}=$ Daily per capita expenditure of $\mathrm{i}^{\text {th }}$ household

$\alpha=$ FGT parameter $(\mu \$ 0)$

$\mathrm{i}=$ individual household 


\section{Results and Discussion}

\subsection{Income and Profitability of Sesame and Soybean Farming systems}

The study revealed (Fig.1.0) that the majority (61\%) of sesame farmers in the study area do not engage in other forms of occupation in contrast to soybean (53\%) farmers who were gainfully employed in other forms of occupation having their highest level of income in the range of $\$ 100,001-500,000$ (Fig 1.1). The implication of this result could be closely linked to their education attainment or awareness of soybean farmers on income diversification which gives them access to other vocational or white-collar job opportunities as compared to the sesame farmers. The result, however, illustrates that both sesame and soybean farmers will have similar income within the N50, 001-100,000 mark which is the mark between the highest income generated by soybean farmers and that generated by sesame farmers. At that point, all things being equal, the standard of living of both sesame and soybean farmers is expected to be the same since income generated from the soybean farming enterprise will be equal to the income generated by sesame farmers.

The farming income of farmers as shown in Figure 3 reveals that the sesame farmers had higher mean income of $\$ 162$, 010.00 accruing from the farming enterprise as compared to that of the soybean farmers' enterprise valued at N75, 795.00 which is less than incomes obtained by soybean farmers in other places (Ugbabe et al. 2017). Notwithstanding the low farming income in the soybean farming enterprise, farmers cultivating soybean tend to have higher income from other forms of occupations they were involved with in the study area as compared to farmers in the sesame farming enterprise. This can be likening to the wider distribution of the education status of farmers in the soybean farming enterprise which gives them gainful employment opportunities in other sectors of the economy thus earning them higher annual income of N204,780.00 (USD 672.88) from off-farm activities. The result also shows that the sesame farmers had a higher mean annual income of N12, 700.00 (USD 41.73) contribution from household members and this implies a likelihood that sesame farmers had members of their household in white collar jobs in the urban areas making a significant contribution to their household needs.

The mean total gross income was $1162,010.00$ (USD 532. 34) and N75, 795.00 (USD 249.05) per hectare for sesame and soybean farmers respectively and the mean total variable cost were N28, 697.00 (USD 94.29) and N15, 476.00 (USD50.85) respectively. While 34\% of sesame farmers hire labour for production purposes, $54 \%$ of soybean farmers were utilizing free household labour (Table 1.0). This underpins the assertion by Dogbe et al. (2013) that the majority of soybean farmers were utilizing household labour for their farming activities in Ghana. The advantage this present to those in the soybean farming system will be less production cost as compared to that of the sesame farmers. However, there is a fair distribution of different labour employed by farmers in the study area which make production to be potentially costeffective. Labour thus constituted the highest average cost of N12, 339.00 (USD 40.60) in the sesame farming enterprise and fertilizer constituted the highest average cost of N8, 965.00 (USD 29.50) in the soybean farming enterprise. The

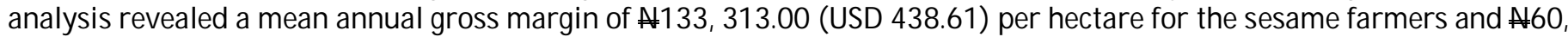
319.00 (USD 198.45) per hectare for the soybean farmers which is more than the gross margin reported by Obasoro et al. (2015) among soybean farmers in Benue state. This higher gross margin demonstrated in the sesame farming system reveals its potentials to be used as an important farming enterprise for rural poverty reduction among farming households. It is also imperative to state that the sesame farmers generated an average annual net profit of N132, 432.96 (USD 435.71) per hectare whereas, the soybean farmers were only generating a net profit of N56, 559.50 (USD 186.08) per hectare which is less than the profit made by soybean farmers in India (Vijaykumar et al. 2014) and Kano State, Nigeria (Ugbabe et al. 2017). The low profit can be attributed to low yield per unit area and the quality of crop output which may have been attracting poor market prices.

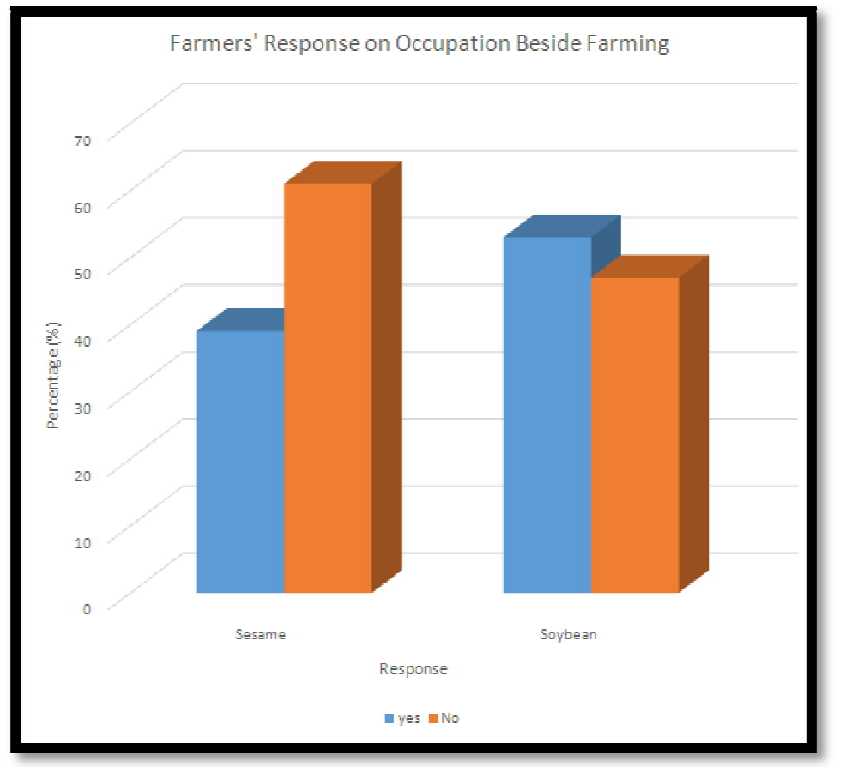

Figure 1: Distribution of Farmers Who Engage in Other Forms of Occupation 


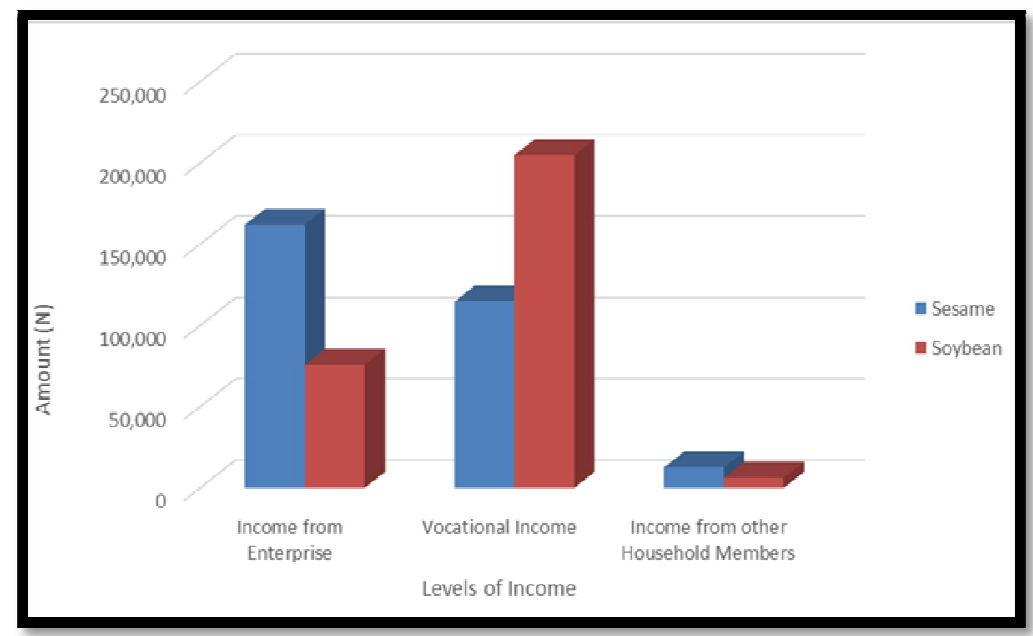

Figure 2: Levels of Farmers' Income in Sesame and Soybean Farming Systems ( $=200)$

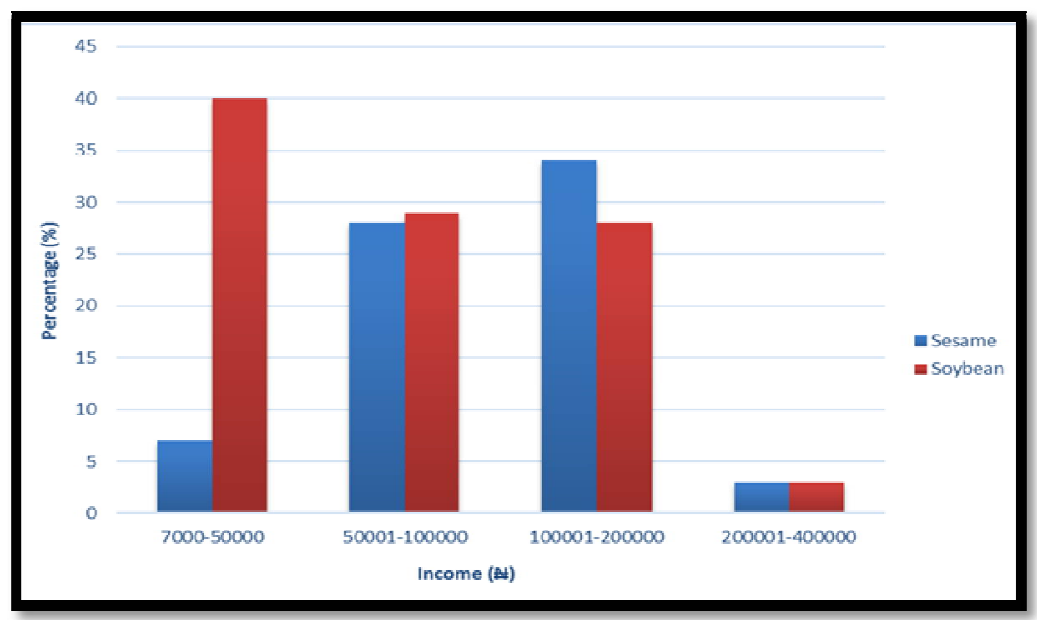

Figure 3: Annual Farming Income Distribution of Sesame and Soybean Farmers $(\mathrm{n}=200)$

\begin{tabular}{|c|c|c|}
\hline & Sesame & Soybean \\
\hline Gross Income $(\mathrm{N})$ & $162,010.00$ & $75,795.00$ \\
\hline Labour cost $(\mathrm{N})$ & $12,339.00$ & $1,803.00$ \\
Fertilizer cost $(\mathrm{N})$ & $9,180.00$ & $8,965.00$ \\
Herbicide cost $(\mathrm{N})$ & $4,524.00$ & $3,166.50$ \\
Pesticide cost $(\mathrm{N})$ & $2,654.00$ & $1,541.00$ \\
Irrigation cost $(\mathrm{N})$ & .00 & .00 \\
Seed cost $(\mathrm{N})$ & .00 & .00 \\
Total Fixed cost $(\mathrm{N})$ & 880.04 & $3,760.00$ \\
\hline Total Variable Cost $(\mathrm{N})$ & $28,697.00$ & $15,476.00$ \\
\hline Total Cost $(\mathrm{N})$ & $29,577.04$ & $19,235.50$ \\
\hline Gross Margin $(\mathrm{N})$ & $133,313.00$ & $60,319.00$ \\
\hline Net Profit $(\mathrm{N})$ & $132,432.96$ & $56,559.50$ \\
\hline
\end{tabular}

Table 1: Gross Margin and Profitability of Sesame and Soybean Farming Systems ( $\mathrm{n}=200)$

\subsection{Poverty Status of Farmers in Sesame and Soybean Farming Systems}

Based on the poverty line set for the study in respect to consumption expenditure of households, the head count index $\left(\alpha_{0}\right)$ was higher (0.9400) amongst farmers in the sesame farming enterprise as compared to that of the soybean farmers (0.9000). This implies that $94 \%$ and $90 \%$ of farmers cultivating sesame and soybean in Benue State were respectively poor which is higher than the $52.3 \%$ poverty level reported among sesame farmers in Jigawa State, Nigeria (Umar et al. 2015). The result further implies that, the majority of the sampled household were having less calories intake per person per day. Considering this analysis based on the food energy intake and the profit made from the two different farming enterprises, it means that the expenditure of sesame farmers on food should be higher. According to OECD and FAO (2016) higher income translates into higher demand for calories and then well-balanced nutritional diet but this was different for sesame farmers in the study area. Sesame farmers were poorer than the soybean farmers in this case and the reason for this could be the ability of soybean farmers to diversify their income by seeking other vocational jobs which may stimulate them to spend more on their calorie intake as compared to the sesame farmers. This implies that soybean 
farmers will be having a more balanced meal than sesame farmers owing to the fact that they may have variety of nutritional options to choose from given their higher food disposable income. It is also important to note that, the lifestyle of sesame farmers, expenditure on other basic needs including health care must have been affecting their household food expenditure. The gap between the poor household and the poverty line reveal that $73 \%$ of sesame farmers in the study area encounter challenges in taking care of their household consumption expenditures as compared to soybean farmers who were rated at the poverty gap of $63 \%$. According to De La O Campos et al. (2018), high poverty gap that exists in most African countries has demonstrated the complexity in solving poverty challenges thus making them open to aids as basis to enhance institutional capacity and sectoral growth. The poverty depth as disclosed in this research hence implies that the farmers' consumption expenditure in the respective farming enterprises was below the poverty line. This means that, if the household income increases, the poverty head count will not change but the poverty gap will decrease to show how the depth of poverty among the farmers has also decreased. The result also reveals that the severity distribution between the poor and the poorest households weighed more (0.6120) among sesame farmers as compared to soybean farmers (0.5190). The implication of this result is that $61 \%$ and $52 \%$ of sesame and soybean farmers were respectively living farther away from the poverty line. Though, more income will be needed to lift sesame farmers above the poverty line as compared to the farmers in soybean farming enterprise.

\begin{tabular}{|c|c|c|}
\hline & Sesame & Soybean \\
\hline Head Count $(\alpha$ 0) & 0.9400 & 0.9000 \\
Poverty Depth $(\alpha 1)$ & 0.7283 & 0.6340 \\
Severity of Poverty $(\alpha 2)$ & 0.6120 & 0.5190 \\
\hline
\end{tabular}

Table 2: Measure of Poverty of Sesame and Soybean Farmers ( $\mathrm{N}=200)$

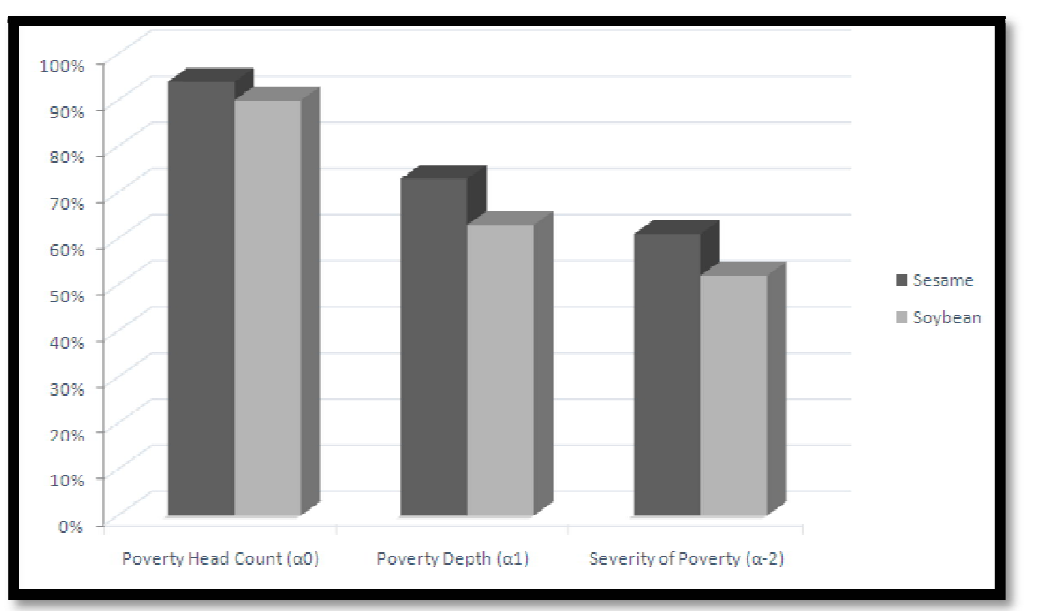

Figure 4: Bar representation of Poverty Status of Farmers in Sesame and Soybean Farming Enterprises ( $\mathrm{n}=200)$

\section{Conclusion and Recommendation}

\subsection{Conclusion}

The research concludes that, the annual income of farmers in the area was fairly distributed among the farming enterprises but sesame farmers were having higher income from their farming enterprise and from other household members who were contributing to the overall welfare of the household as compared to the soybean farmers. On the other hand, soybean farmers were having an improved level of income distribution from off-farm activities as compared to the sesame farmers. The research also reveals a reasonable average annual gross margin for both farming enterprises but the gross margin of sesame farmers was higher than that of the soybean farmers. In addition, sesame farmers were making more profit from their farming business as compared to farmers cultivating soybean in Benue State. This shows the potentials of sesame as an important farming enterprise to be utilized towards rural farmers' livelihood improvement; hence, there is no need for farmers to make a cultivation shift from sesame to soybean farming enterprise but diversification into the cultivation of different oilseed crops should be encouraged to tap into the global initiative of biofuel substitution. The result of the determination of farmers' poverty status implies that majority of both sesame and soybean farmers were living below the poverty line. This can be linked to low yield and poor-quality output which makes them less efficient to compete in the market on a global scale. In order to eliminate poverty in the respective farming enterprises, the sum of all the poor people's poverty gap will have to be taken under consideration (Taylor and Lybbert 2015), however the square of the poverty gap will give the exact idea of the income that will be needed to bring all households above the poverty line. Therefore, more income will be needed to bring sesame farmers above the poverty line as compared to the soybean farmers.

\subsection{Recommendations}

Based on the findings from this study, it is expedient to recommend that, there is need to sustainably intensify the cultivation of sesame and soybean in the study area owing to their good income and profit potential. Further, this will 
create a better thriving export market for oilseed in Nigeria, encourage its processing to more finished products and make more income available to farmers thus improving their livelihood.

There is also the need to encourage income diversification among farmers at the household level to enable them acquire more income to take care of their basic household needs as experienced by soybean farmers in Benue state. This can be achieved by developing the rural non-farm sector and diversifying into the production of crops with short life cycle which can be grown multiple times within a production season to help improve household food provision and income.

\section{References}

i. Abu, G. A, Abah, D. and Okpachu, S.A. (2011). Analysis of Cost and Return for Sesame Production in Nasarawa State: Implication for Sustainable Development in Nigeria. Journal of Sustainable Development in Africa. 13(3):238-249.

ii. Abu, G.A., Ater, P.I. and Abah, D. (2012). Profit Efficiency among Sesame Farmers in Nasarawa State, Nigeria. Current Research Journal of Social Sciences 4(4): 261-268.

iii. Agele, S. O., Oladitan, T. O. and Olarewaju1 A. T. (2015). Growth and Yield Performance of Sesame (Sesamum indicum L.) in the Rainforest and Derived Savanna Agro-ecologies of Nigeria. International Journal of Agricultural Policy and Research. 3(6):279-286.

iv. Ayana, N. G. (2015). Status of Production and Marketing of Ethiopian Sesame Seeds (Sesamum indicum L.): A Review. Agricultural and Biological Science Journal 1(15):217-223.

v. Bellù, L. G. and Liberati, P. (2005). Impacts of Policies on Poverty. Absolute Poverty Lines. Food and Agriculture Organization of the United Nations, (FAO), Rome.

vi. De La O Campos, A. P., Villani, C. Davis, B. and Takagi, M. (2018). Ending Extreme Poverty in Rural Areas. Sustaining Livelihoods to Leave No One Behind. FAO, Rome. Available at http:/ / www.fao.org/ 3/ CA1908EN/ ca1908en.pdf

vii. Glin, L.C., Mol, A. P. J. and Oosterveer, P. (2013). Conventionalization of the Organic Sesame Network from Burkina Faso: Shrinking into Mainstream. Agric Hum Values. 30:539-554.

viii. Gupta, S. K. (2015). Breeding Oilseeds Crops for Sustainable Production. Opportunities and Constraints. Academic Press. Pg.147, 293-310.

ix. Jensen, R. T. and Miller, N. H. (2010). A Revealed Preference Approach to Measuring Hunger and Undernutrition. The National Bureau of Economic Research. Working Paper No. 16555. Available at http:/ / www.nber.org/ papers/ w16555 (Accessed 30th August, 2016).

x. Nyiatagher, Z. T. and Ocholi, A. (2015) Gross Margin Analysis and Resource Use Efficiency in Sesame Production among Small- Scale Farmers in Benue State, Nigeria. IOSR Journal of Agriculture and Veterinary Science. 8(7):1523.

xi. Nzeka, U. M. (2014). Nigeria Provides Export Market for Oilseeds and Products. GAIN Report. Available at http:/ / gain.fas.usda.gov/ Recent\%20GAIN\%20Publications/ Nigeria\%20Provides\%20Export\%20Market\%20for\% 20Oilseeds\%20and\%20Products_Lagos_Nigeria 6-2-2014.pdf (Accessed 16th May, 2016).

xii. OANDA (2016). Currency Converter. Available at https:// www.oanda.com/ currency/ converter/ (Accessed 28 September, 2016)

xiii. Obasoro O.A., Iwinlade A., Popoola O. and Adeoti A.I.(2015). Effect of Adoption of Improved Soybean Variety on Productivity of Farm Households in Benue State, Nigeria. Legume Genomics and Genetics.6 (6):1-9.

xiv. OECD and FAO (2016). OECD-FAO Agricultural Outlook 2016-2025. OECD Publishing, Paris.

xv. Olowe, V.I.O., Adeyemo, Y.A. and Adeniregun, O.O. (2009). Sesame: The Under-Exploited Organic Oilseed. Journal of Science and Sustainable Development 2: 29-32.

xvi. Ravallion, M. (2010). Poverty Lines across the World. Policy Research Working Paper 5284. The World Bank Development Research Group. Available at https:/ / openknowledge.worldbank.org/ bitstream/ handle/ 10986/ 3771/ WPS5284.pdf?sequence=1（Accessed 18th August, 2016).

xvii. Singh, R., Upadhyay, A. K., Shrivastava, P., Singh, V. K. and Singh, S. K. (2014). Productivity Enhancement of Sesame (Sesamum indicum L.) through Improved Production Technologies. Bioscan. 9(1):107-110.

xviii. Taylor, E. J. and Lybbert, T. J. (2015). Essentials of Development Economics. University of California Press. Pp. 9499.

xix. Ugbabe, O. O., Abdoulaye, T., Kamara, A. Y., Mbavai, J. and Oyinbo, O. (2017). Profitability and Technical Efficiency of Soybean Production in Northern Nigeria. Tropicultura 35(3):203-214.

xx. Uker, S. and Orkar M. O. (2019). Implication of Violent Conflict on Food Security in Nigeria: A Case of Farmers and Herdsmen Clashes in the Benue Valley. International Journal of Science and Research (IJSR) 8(8):627-631. https:/ / www.ijsr.net/ archive/ v8i8/ show abstract.php?id=ART201910008.

xxi. Umar, H. S. Okoye, C. U. and Agwale, O. A. (2011). Productivity Analysis of Sesame (Sesamum indicum L.) Production under Organic and Inorganic Fertilizers Applications in Doma Local Government Area, Nasarawa State, Nigeria. Tropical and Subtropical Agroecosystems, 14: 405-411.

xxii. Umar, H.S. and Ibrahim, H.Y (2012). Energy Use and Gross Margin Analysis for Sesame Production in Organic and Inorganic Fertiliser User Farms in Nigeria. African Crop Science Journal. 20(1):39-4.

xxiii. Umar, S., Abdu, Z. and Ahmad, M.M. (2015). Analysis of Poverty Status of Rural Smallholder Sesame Farmers in some Selected Local Government Areas in Jigawa State, Nigeria. Journal of Agricultural Economics, Extension and Rural Development. 3(7):303-309. 
xxiv. Vijaykumar, N., Patil, S. S., Goudappa, S. B. (2014). Socio-economic characteristics of Soybean Growers with Existing and Alternative Farm Plans in Latur district of Maharashtra. International Journal of Agricultural Sciences. 10(1):378-381. 